\title{
BONDED POROUS REVETMENTS - EFFECT OF POROSITY ON WAVE-INDUCED LOADS AND HYDRAULIC PERFORMANCE
}

\author{
Sven Liebisch', Juan Carlos Alcérreca Huerta ${ }^{1}$, Andreas Kortenhaus ${ }^{1}$, Hocine Oumeraci $^{1}$
}

The porosity and roughness of bonded revetments are both crucial for the hydraulic performance and the wave loading of the revetment and its foundation, and thus for the stability and durability of the entire structure. This is briefly shown by the selected results of a tentative comparative analysis of two large-scale test series performed in the Large Wave Flume (GWK) Hanover with two significantly different revetments: a highly porous and rough polyurethane bonded aggregate (PBA) revetment and an almost impermeable and relatively smooth interlocked pattern placed block (IPPB) revetment. These results motivated the initiation of the three years research project BoPoRe (Bonded Porous Revetments) which has the primary objective to investigate more systematically and separately the relative importance of both porosity and roughness for different slope steepnesses. This project is briefly introduced and the first results of preliminary scale model tests using 9 configurations for the porosity and roughness of the revetment subject to a wide range of wave conditions (surf similarity parameters $\xi_{\mathrm{m}-1,0}=0.93-7.21$ ) are briefly discussed.

Keywords: bonded porous revetment; hydrodynamic processes; wave-induced loads

\section{INTRODUCTION}

Bonded porous revetments (see Figure 1) are used increasingly as innovative coastal protection structures at coastal areas subject to high wave loads (Oumeraci et al. 2010 \& Oumeraci et al. 2012). The application of these types of revetments offers some advantages compared to conventional nonbonded revetments due to their high porosity as well as to the force-fit and flexible connections between the single elements. With the high porosity combined with the durable elastic bonding smaller stones in the upper layer of the revetment and a smaller revetment thickness are required to resist the design load, and hence significant may be feasible.

However, to date no detailed studies are yet available which systematically account for the effect of the porosity on the hydraulic performance (e.g. wave reflection, wave run-up and run-down) and the wave-induced loads on the revetment and its foundation. The existing formulae do not take the connection of the single elements nor the porosity of the revetment itself into account. Although porous bonded revetments may become more important in the near future, the current design practice does not consider the porosity of the revetment explicitly (see e.g. EurOtop 2007, CIRIA/CUR/CETMEF 2007).

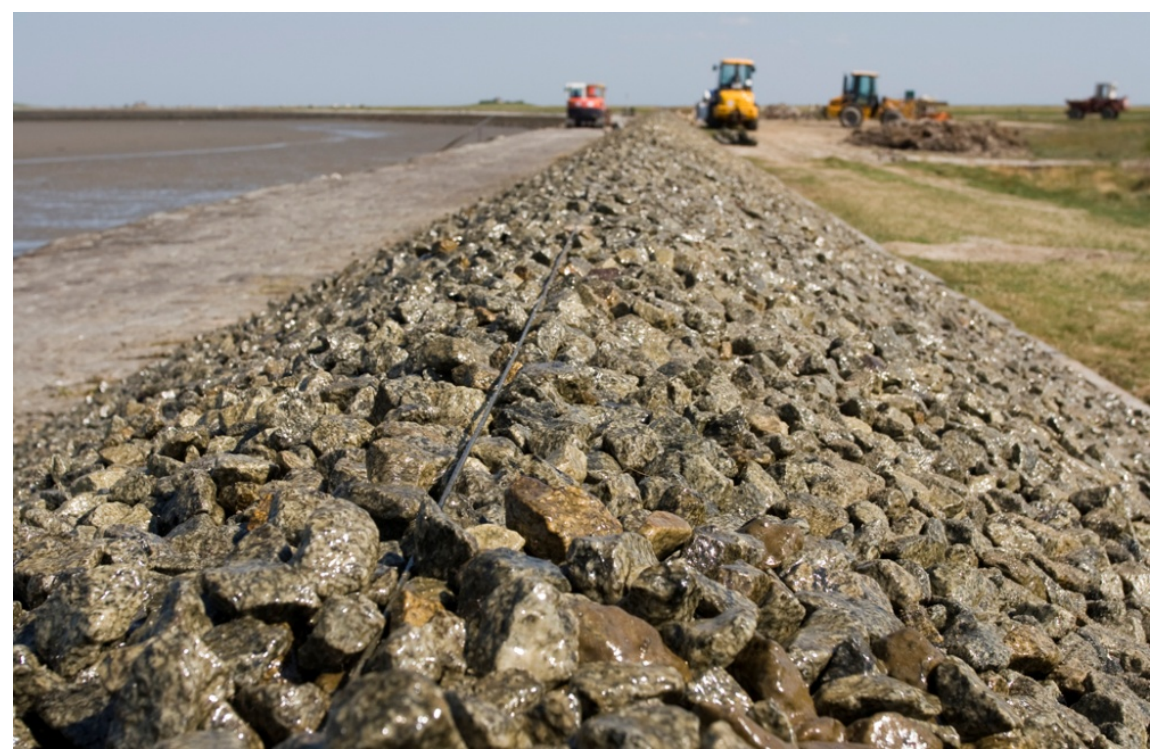

Figure 1. Polyurethane bonded aggregate (PBA) revetment (photo: BASF)

\footnotetext{
${ }^{1}$ Leichtweiß-Institute for Hydraulic Engineering and Water Resources, Department of Hydromechanics and Coastal Engineering, Technische Universität Braunschweig, Beethovenstraße 51a, 38108 Braunschweig, Germany; contact author: sven.liebisch@tu-bs.de
} 
Recent investigations (Oumeraci et al. 2010 \& Oumeraci et al. 2012) indicated that the preservation of the porous structure is of fundamental importance due to its effect on the hydraulic performance and on the wave loading of the revetment and its foundation. Especially aging processes, marine growth (e.g. barnacles or shells, growing on and in the revetment) and sediment deposition in the pores may affect the porosity of the structure over time. In this context, it is crucial to know the porosity reduction which may substantially affect the wave loads and the hydraulic performance, and which may thus result in structural or functional failures.

Two series of tests with different bonded revetments were recently performed in the Large Wave Flume (GWK) of the "Forschungszentrum Küste" (FZK) in Hanover, Germany. In the first test series, a polyurethane bonded aggregate revetment, called hereafter "PBA revetment", was investigated in terms of hydraulic performance, wave loads and subsoil response (Oumeraci et al. 2010 \& Oumeraci et al. 2012). The second test series were performed in 2011 by the RWTH Aachen, Institute of Hydraulic Engineering and Water Resources Management (IWW) in order to investigate different revetments made of interlocked pattern placed blocks, called hereafter "IPPB revetment" (Gier et al. 2011 \& Gier et al. 2012). In both cases an extensive testing and measuring programme was performed to investigate wave-induced loads on and underneath the revetment together with wave run-up and run-down.

The paper will first discuss some selected results from the comparative analysis of these largescale model tests by focusing on the comparison between the wave reflection as well as on the wave loads on and beneath the two types of revetments. The results of the comparative analysis of the wave run-up are reported by Schimmels et al. (2012).

Based on the results of these tests and in order to enhance the knowledge of the interaction of hydrodynamic and hydrogeotechnical processes due to wave loads on and beneath porous bonded revetments, the research project BoPoRe (Bonded Porous Revetments), funded by the German Research Council (DFG), was initiated. This BoPoRe project and the underlying methodology are briefly outlined.

Finally the first results of preliminary scale model tests using 9 configurations by varying the porosity and roughness of the revetment (with a fixed slope 1:3) subject to a wide range of wave conditions (surf similarity parameter $\xi_{\mathrm{m}-1,0}=0.93-7.21$ ) are briefly discussed, also including an outline of the next steps of the BoPoRe project.

\section{LARGE-SCALE MODEL TESTS IN THE LARGE WAVE FLUME (GWK)}

\section{Model set-up}

The aforementioned two large-scale test series were performed in the Large Wave Flume (GWK) in Hanover, Germany with a length $1=330 \mathrm{~m}$, a depth $\mathrm{d}=7 \mathrm{~m}$, and a width $\mathrm{w}=5 \mathrm{~m}$. These test series are discussed below in more detail:

Highly porous PBA-revetment. Oumeraci et al. (2010) conducted model tests on a PBA revetment. Three model alternatives with an identical slope 1:3 and an identical cover layer thickness of $t_{R}=0.15 \mathrm{~m}$ made of polyurethane bonded stones $(20 / 40 \mathrm{~mm})$ with a porosity of $\mathrm{p}=48 \%$ were tested. This porosity is defined by percentage of pore volume in relation to the total volume. The revetments were distinguished by different thicknesses of the gravel under layer (Model A: $t_{R}=0.0 \mathrm{~m}$; Model B: $t_{R}=0.10 \mathrm{~m}$ and Model $\mathrm{C}: \mathrm{t}_{\mathrm{R}}=0.20 \mathrm{~m}$ ). Two of these three alternatives were built side by side, each covering one half of the wave flume and were tested simultaneously under the same wave conditions (Phase 1: Model A and B; Phase 2: Model B and C). A thin plywood sheet was used to separate the two models. Model A had to be replaced by Model C in phase 2 because of a failure of the revetment during phase 1 . The layers of the Model $\mathrm{C}$ revetment are illustrated in Figure 2.

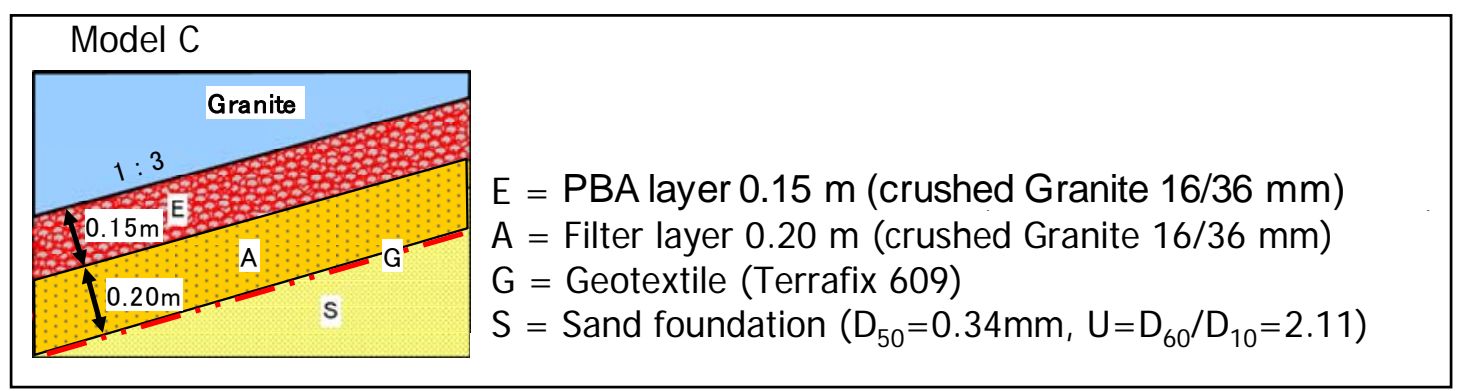

Figure 2. Model Alternative $C$ built after failure of Model Alternative A (Oumeraci et al. 2012) 
More than 80 measuring devices were deployed to measure synchronously the waves in the far and near field, wave run-up and run-down, run-up layer thickness and velocity, pressures on and just beneath the revetment, pore pressure in the subsoil as well as motions of the revetment normal to the slope. Model tests were conducted with a very broad variation of the wave conditions (surf similarity parameters $\xi$ between ca. 1.5-7) for both regular and irregular waves. The tests with regular waves were used to understand the processes involved in the wave-structure foundation interaction while the irregular wave tests were primarily used to develop empirical formulae for design purposes. More details on the model set-up, on the deployed measuring and observation techniques and on the testing programme can be found in Oumeraci et al. (2012).

Low permeable interlocked pattern placed block revetment (IPPB). In 2011 the RWTH Aachen, Institute of Hydraulic Engineering and Water Resources Management (IWW) (Gier et al. 2011) investigated different revetments made of interlocked concrete blocks on a slope of 1:3 in GWK. These different interlocked blocks all had a similar low porosity of $\mathrm{p}=3 \%$. The main objective of these tests was the determination of the revetment stability against wave loads. The entire model set-up is similar to model alternative B in the afore described model tests with the high porous revetment. The interlocked blocks were placed on a granular filter with a layer thickness of $t_{R}=0.10 \mathrm{~m}$. All model alternatives were underlayed by a geotextile on a sand core. The model set-up is shown in Figure 3.

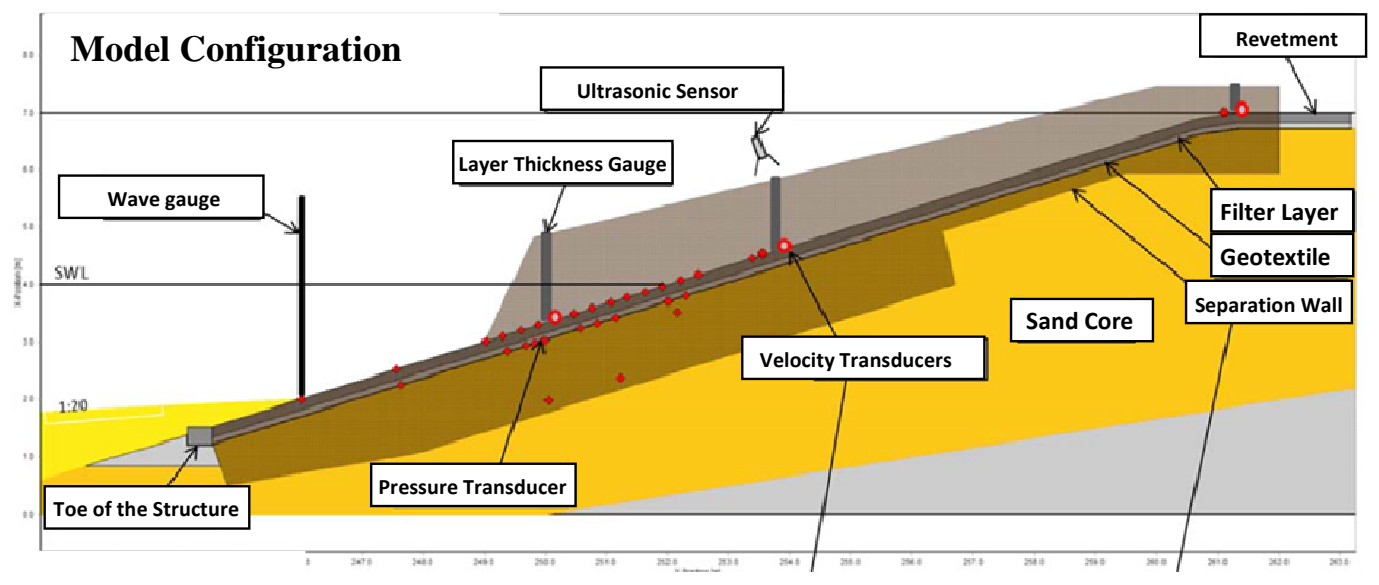

Figure 3. Exemplary cross section with measuring devices of the IPPB revetment in GWK (modified from on Gier et al. 2011)

In these model tests, a separation wall was also used to divide the two different revetment types that were investigated simultaneously. However, the test programme was mainly focused on irregular wave conditions leading to plunging breakers with surf similarity parameters $\xi<2.6$. The locations of the measuring devices on and beneath the revetment were similar to those on the PBA revetment model tests which allowed for a direct comparison of the results. The photographs in Figure 4 show the different revetments under wave attack in GWK. 


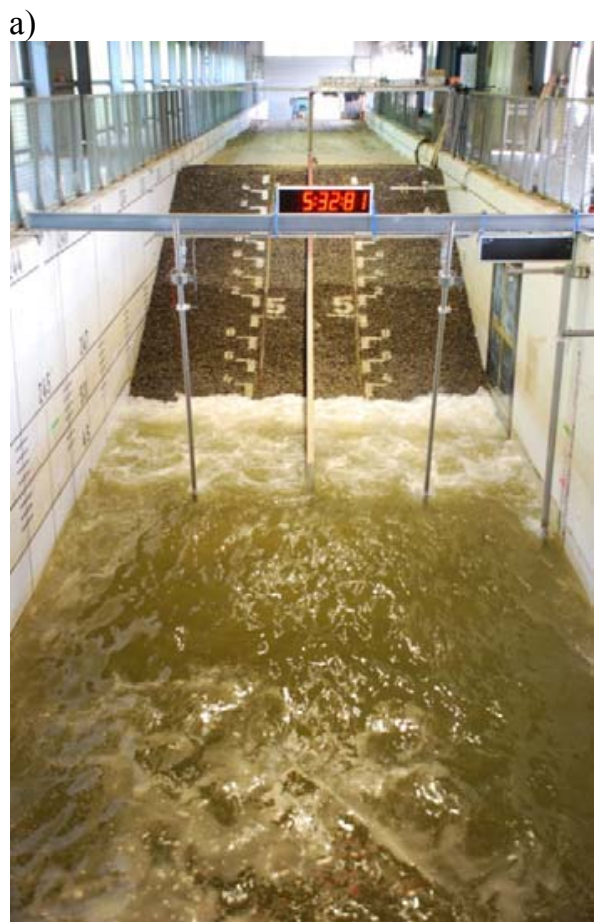

b)

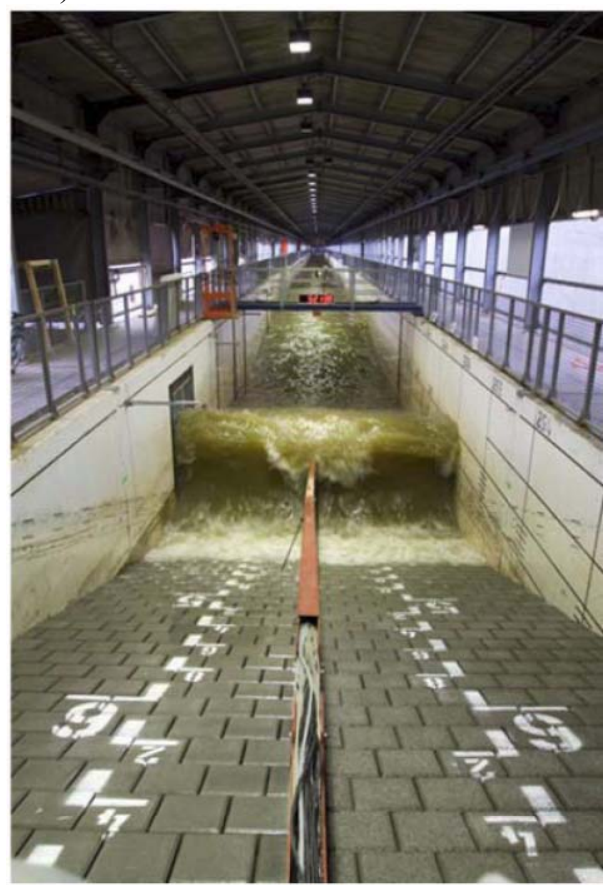

Figure 4. Photos of the different revetments under wave attack in GWK: a) PBA revetment (Oumeraci et al. 2010), b) IPPB revetment (Gier et al. 2011)

\section{Comparative Analysis: Selected results}

Alcérreca Huerta \& Oumeraci (2012b) performed a detailed comparative analysis of the largescale tests of the two types of revetments with significantly different porosities $(\mathrm{p}=3 \%$ for IPPB revetment and $\mathrm{p}=48 \%$ for PBA revetment). Some of the results are summarized below.

Wave reflection. In Figure 5 reflection coefficient $C_{r}$ for different surf similarity parameters is illustrated for the two different revetments together with the basic fitting line of Seelig (1983) for a smooth impermeable slope.

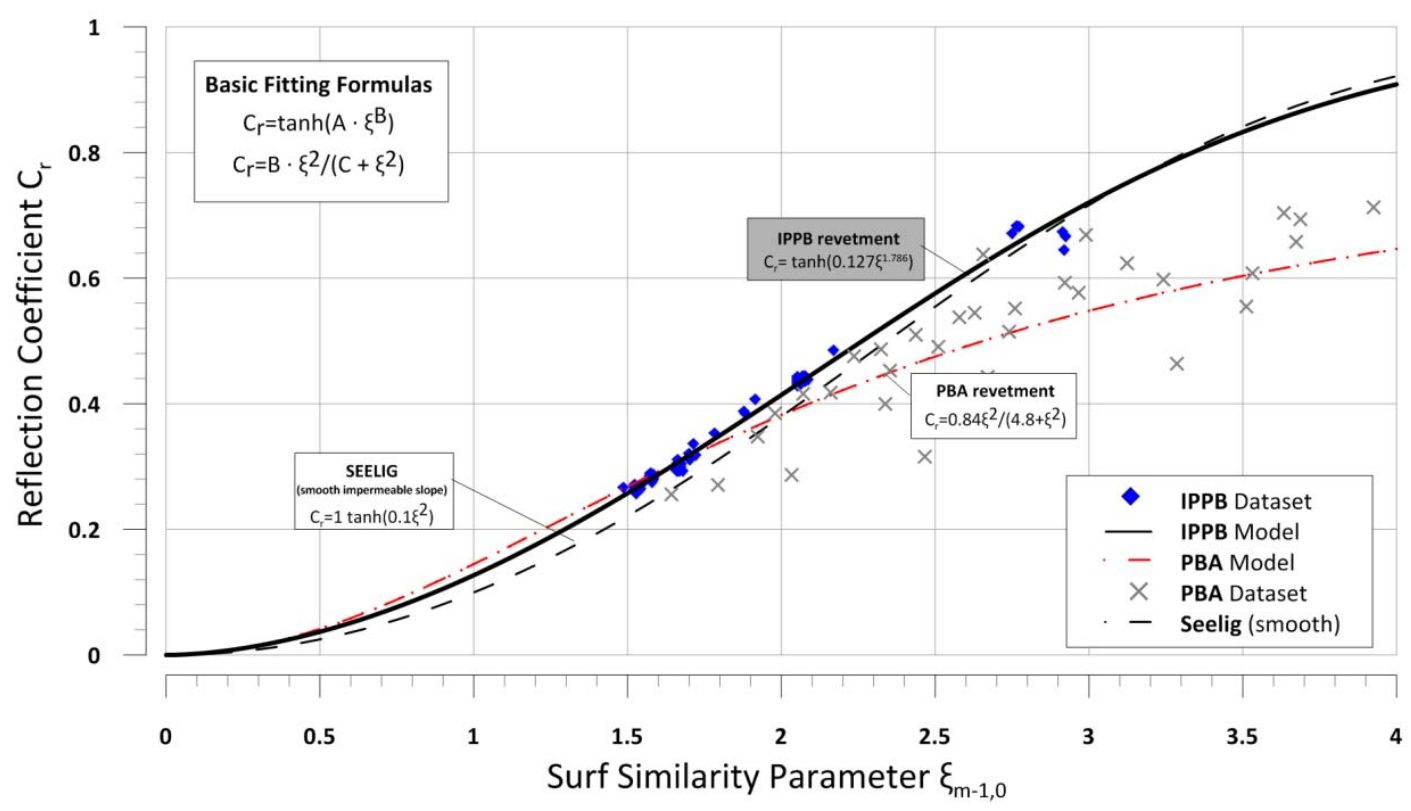

Figure 5. Reflection coefficient $C_{r}$ plotted against the surf similarity parameter $\xi_{m-1,0}$ for wave spectra (Alcérreca Huerta \& Oumeraci 2012b) 
In case of the IPPB revetment the reflection coefficient was well described by a function of the surf similarity parameter as indicated in Figure 5 and given in Eq. (1). It can be seen that the IPPB revetment behaves like a smooth impermeable slope which may have been expected due to the greatly smoother slope and to the very low porosity $(p=3 \%)$. The reflection coefficient $C_{r}$ for the IPPBdataset for wave spectra is given by:

$$
C_{r}=\tanh \left(0.127 \cdot \xi^{1.786}\right)
$$

For the PBA revetment some scatter occurred which suggested that also the porosity has to be taken into account for the analysis. Due to the porosity and the roughness of the PBA revetment a reflection coefficient results which is about 30\% smaller than that of the IPPB revetment for large surf similarity parameters leading to non-impact loads. However, Oumeraci et al. (2010) used another fitting function for the reflection coefficient $C_{r}$ which has also been proposed by Seelig (1983), leading to:

$$
C_{r}=\frac{0.84 \cdot \xi^{2}}{4.8+\xi^{2}}
$$

Consequently, problems associated with reflected waves, like scouring at the toe of the structure or the affection of incident waves (wave-wave interaction) are more likely to occur for the IPPB revetment. The effect of the porosity and the roughness of the revetment on wave reflection needs to be investigated in more detail and separately.

Peak pressure on the revetment. The porous structure is assumed to also affect the waveinduced loading of the revetment. Therefore, in Figure 6, the relative maximum pressures on the revetment for different surf similarity parameters $\xi_{\mathrm{m}-1,0}$ are compared for the IPPB and the PBA revetment. It has to be pointed out that a complete comparison is not possible, because the range of the surf similarity parameter in the experiments with the IPPB revetment $\left(\xi_{\mathrm{m}-1,0}<2.6\right)$ was not as wide as for the PBA revetment $\left(\xi_{\mathrm{m}-1,0}=1.6-6.6\right)$.

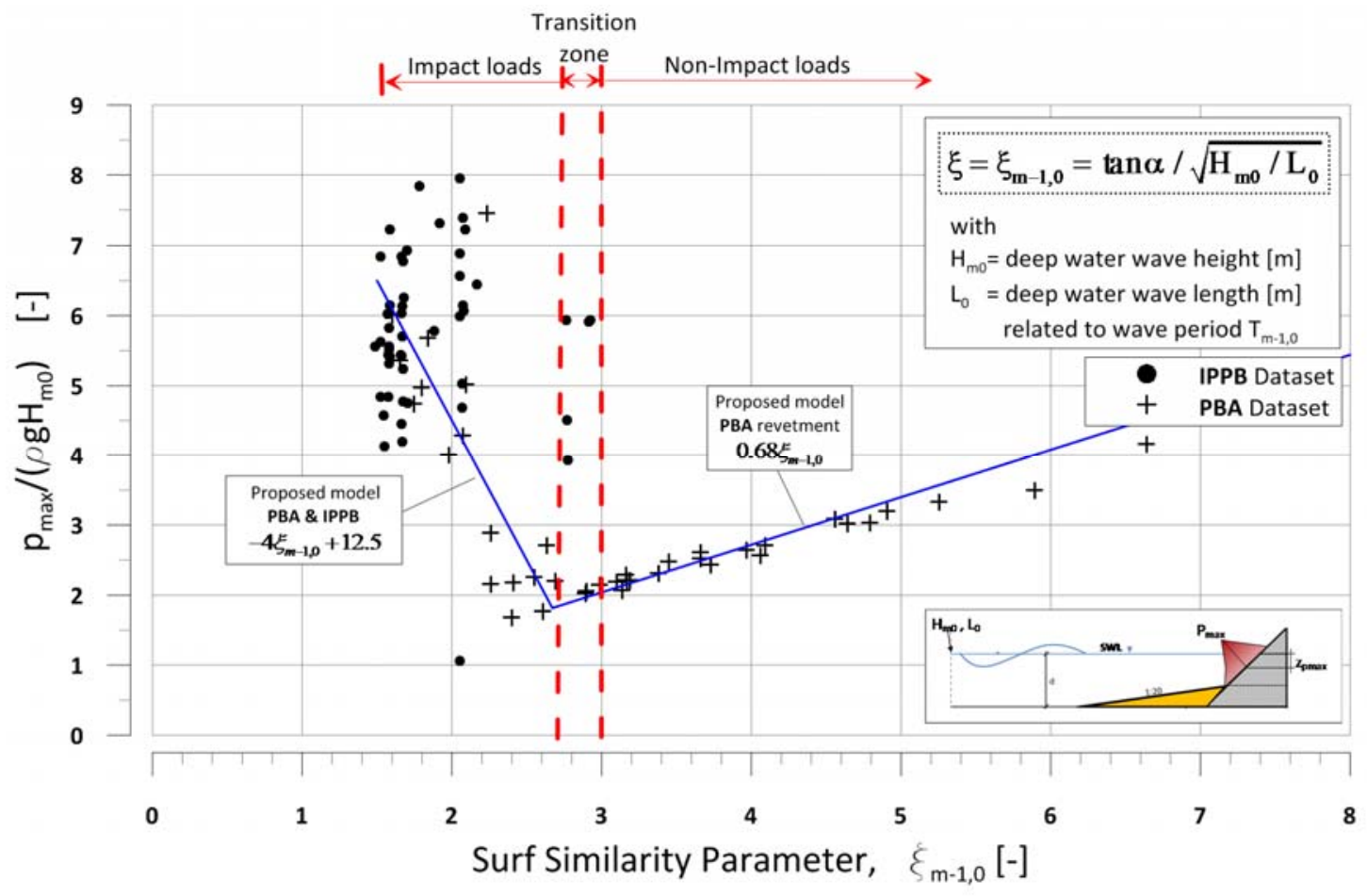

Figure 6. Relative maximum pressures on the revetment plotted against surf similarity parameter $\xi_{\mathrm{m}-1,0}$ for wave spectra (Alcérreca Huerta \& Oumeraci 2012b) 
It is obvious in Figure 6 that for both revetments maximum pressures occur for plunging breakers with a surf similarity parameter $\xi_{\mathrm{m}-1,0}$ smaller than 2.0. Also, a large scatter can be noticed and, according to Alcérreca Huerta \& Oumeraci (2012b), the surf similarity parameter is not the sole parameter describing the relative maximum pressure on the IPPB revetment and there are more parameters affecting these maximum pressures. Nevertheless, it can be seen that the peak pressures on the IPPB revetment are significantly higher than for the PBA revetment (for the same wave conditions), where small changes in wave conditions can lead to a rapid increase of the relative pressure values. Thus, the porous structure tends to receive lower peak pressures on the revetment. Alcérreca Huerta \& Oumeraci (2012b) adopted the model for the description of the relative maximum pressure on the revetment which was proposed by Oumeraci et al. (2010) for the permeable PBA revetment as follows:

$$
\frac{p_{\max }}{\rho g H_{m 0}}=-4 \xi_{m-1,0}+12.5 \text { for } \xi_{m-1,0}<2.7
$$

It has to be noted that for $1.5<\xi_{\mathrm{m}-1,0}<2.0$, equation (3) can underestimate relative pressure peaks for the IPPB revetment.

Eq. (4) for larger surf similarity parameters $\xi_{\mathrm{m}-1,0}>2.7$ is only valid for the observed PBA revetment because of the afore mentioned lack of data for the IPPB revetment.

$$
\frac{p_{\max }}{\rho g H_{m 0}}=0.68 \xi_{m-1,0} \text { for } \xi_{m-1,0}>2.7
$$

These findings lead to the assumption that it is likely that a reduction of pore volume by sediment deposition or marine growth can lead to an increase of the maximum pressures on the revetment. The latter has to be taken into account for the performance and the maintenance of the revetment.

Pressure time series on and beneath the revetment. There are not only differences in the magnitudes of the peak pressures on both types of revetments, but also in the shapes of the peaks. Figure 7 shows two time series of pressures on the two different revetments: a) on the highly porous PBA revetment and $b$ ) on the almost impermeable IPPB revetment. The wave-induced pressures on the cover layer are illustrated by the blue line and pressures underneath the revetment are indicated by the red line for the same wave conditions (here: regular waves with a wave height $\mathrm{H}_{\mathrm{m}}=1.0 \mathrm{~m}$ and a wave period of $\left.\mathrm{T}_{\mathrm{m}}=4.0 \mathrm{~s}\right)$. 
a) Highly porous PBA revetment

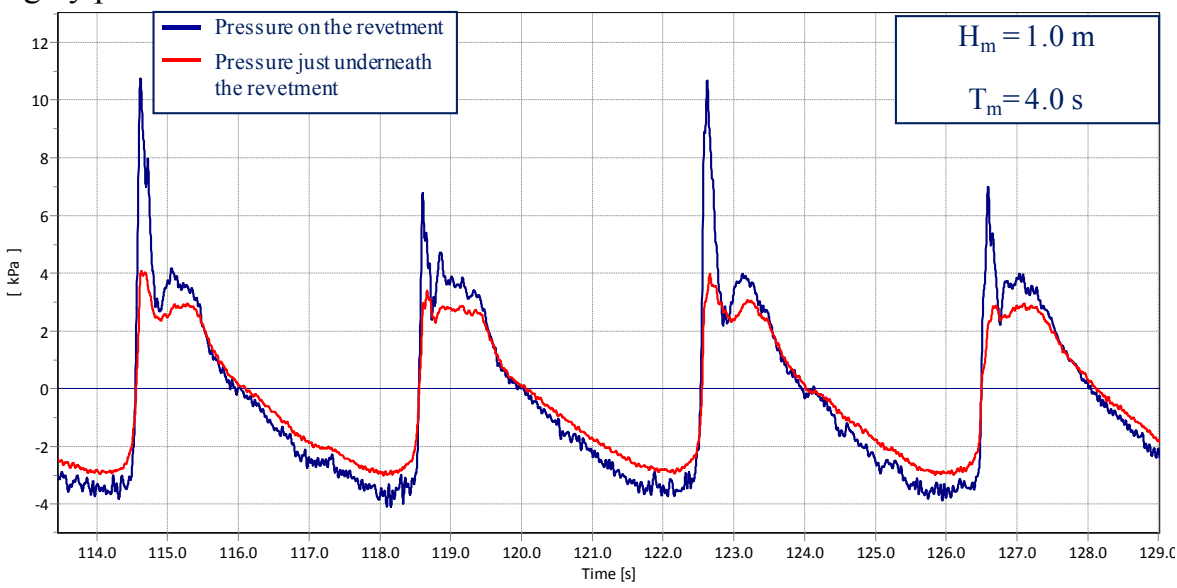

b) Almost impermeable IPPB revetment

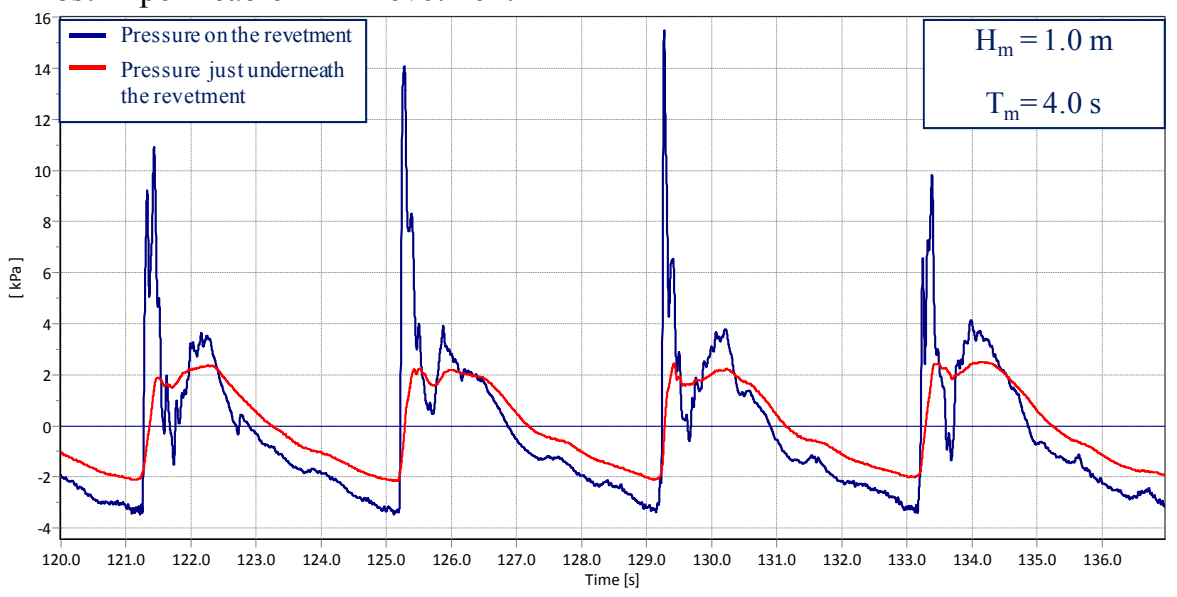

Figure 7. Time series of wave-induced pressures on and beneath a) the highly porous PBA revetment and b) the almost impermeable IPPB revetment

It can be seen in Figure 7 that the pressure peaks are not damped completely under the highly porous revetment whereas nearly no peaks can be seen under the almost impermeable IPPB revetment. Furthermore, the behaviour of the pressures underneath the two types of revetments in time differs significantly. In comparison to the highly porous PBA showing two distinct peaks (dynamic and quasistatic) on the pressure histories occurring almost simultaneously on and beneath the revetment, the peak pressure is not noticeable beneath the IPPB revetment. Furthermore, the pressure time histories on and beneath the revetment show a more significant time-shift.

Moreover, a typical phenomenon can be seen in Figure $7 \mathrm{~b}$ for the almost impermeable IPPB revetment. After the impact, the pressure is oscillating in contrast to the smooth pressure signal on the highly porous revetment in Figure 7a. This might be explained by the entrapped air under the breaking wave or by the oscillating movement of the instrumented revetment block. Further investigations are still required to clarify the origin of these pressure oscillations for the IPPB revetment case.

Spatial distribution of pressures induced by plunging breakers on the revetment. A comparison of the spatial pressure distribution was only possible for impact loads with a surf similarity parameter smaller than 2.5 (impact load by plunging breakers), since other breaker types were not investigated in the IPPB revetment test series. The pressure distributions on the two types of revetments are illustrated in Figure 8. Oumeraci et al. (2010) used a linear distribution described by five points for the spatial pressure distribution on and beneath the revetment in a normalized representation. This normalized representation was also adopted by Alcérreca Huerta \& Oumeraci (2012b), because of the advantage of estimating the dimensionless pressure over the entire height of the revetment. Figure 8 shows the triangular shape of the spatial pressure distribution for the PBA revetment with two linear parts land- and seaward of the pressure peak. Alcérreca Huerta \& Oumeraci 
(2012b) found a wider impact area and thus a smoother shape for the impact load on the IPPB revetment (Figure 8).

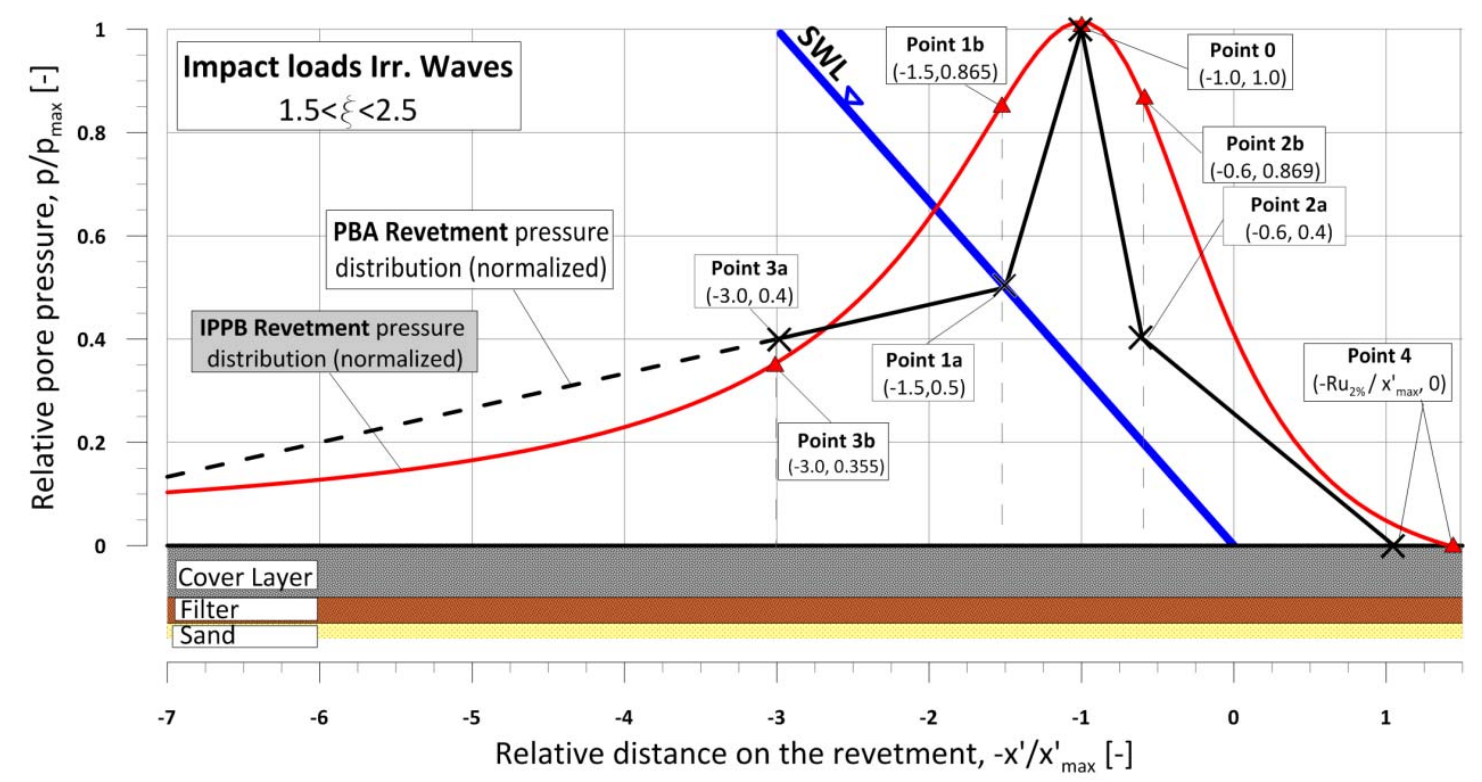

Figure 8. Comparison of the spatial pressure distribution models suggested for the PBA and the IPPB revetment for irregular waves and impact loads (Alcérreca Huerta \& Oumeraci 2012b)

Wave-induced pore pressures in the sand core beneath the revetment. For both types of revetments (PBA and IPPB) tested in GWK the same sand material was used for the core of the embankment. However, the pressure transducers were not placed exactly in the same locations, and therefore a comparison could only be made by considering normalized pressures (Alcérreca Huerta \& Oumeraci 2012b) In this case, again, a comparison was also only valid for surf similarity parameters between 1.5 and 2.7 leading to impact loads. The transmission of the pressures through the different layers is very important for the analysis of the pore pressures in the sand core, because the pressure at the top of the sand layer $\left(\mathrm{p}_{0}\right)$, which is the reference pressure for the pore pressure calculations, has to be determined. Oumeraci et al. (2010) derived general equations for the pore pressure development dependent on the depth in the sand layer $(\mathrm{z})$, the deep water wave length $\left(\mathrm{L}_{0}\right)$ and the surf similarity parameter $\left(\xi_{\mathrm{m}-1,0}\right)$. It was considered that the pressure at the top of the sand layer decreases exponentially with dimensionless depth $z / \mathrm{L}_{0}$. Eq. (5) shows an example for a surf similarity parameter of $\xi_{\mathrm{m}-1,0}=2.0$ :

$$
\frac{p_{\left(z^{\prime}\right)}}{p_{0}}=0.96 \exp \left(-127 z / L_{0}\right)+0.04 \text { for } \xi_{m-1,0}=2.0
$$

Since the material of the sand core was the same for the PBA and IPPB revetment tests, any difference in the development of the pore pressure due to different soil properties is to be excluded.

For the PBA revetment, the initial value of the pressure considered at the top of the sand layer beneath the revetment is reduced to about $50 \%$ at a depth of $0.2 \mathrm{~m}$ inside the sand core, and to $14 \%$ at a depth of $0.80 \mathrm{~m}$. For the IPPB revetment the reduction of the initial pressure is about $5-10 \%$ less than for the PBA revetment (Alcérreca Huerta \& Oumeraci 2012b).

Despite the similar damping process in the sand core on both revetments, the cover and the filter layer properties (i.e. material, thickness, permeability and porosity) are very important for the transmission of the pressure from the top of the revetment to the top of the sand layer. In this way, the magnitude of the pore pressure at the top of the sand layer $\left(\mathrm{p}_{0}\right)$, that should be damped afterwards by the sand core, differs for the PBA and IPPB revetments: higher pore pressures $\mathrm{p}_{0}$ at the top of the sand core were obtained for a PBA revetment than for an IPPB revetment (Alcérreca Huerta \& Oumeraci 2012b). Consequently, the expected pore pressures inside the sand core beneath a PBA revetment are higher than those beneath an IPPB revetment (see eq. (5)). 
Moreover, it should be stressed that the afore mentioned differences between the two types of revetment in terms of the damping of wave pressure transferred to the deeper layers are only valid for the pressures generated by impact loads. For the quasi-static loads, however, the pressure damping induced by the cover layer is negligibly small and most of the damping of the quasi-static pressure takes place within the filter layer and the sand core for both types of revetments.

\section{Discussion of the results of the comparative analysis}

The selected results, briefly described above and further results of the comparative analysis performed by Alcérreca Huerta \& Oumeraci (2012b), clearly indicate that the preservation of the revetment porosity over time is crucial for the hydraulic performance and the wave loading of bonded porous revetments and their foundation and thus for the stability and durability of the entire structure. It is however not fully clear to distinguish between the effect of the porosity and the roughness of the revetment, particularly with respect to the reflection behaviour, which is significantly higher for the almost impermeable and smooth IPPB revetments. Moreover, both porosity and roughness of the revetment affect (i) wave run-up and run-down which are generally reduced in case of the PBA revetment and (ii) the impact load on the revetment showing a similar peak pressure, but a wider impact area and a smoother shape of the pressure over the entire height of the structure. Furthermore, the maximum peak pressures on the revetment are transferred more distinctively and without any noticeable time shift through the highly porous PBA revetment leading to a higher pressure beneath the revetment and in the underlying core. Due to a change in porosity a change of the spatial pressure distribution is possible.

The results imply that more systematic investigations are needed to quantify separately the relative importance of the porosity and the roughness of the revetment as well as the threshold values of theses revetment properties at which their effect becomes negligibly small.

\section{THE RESEARCH PROJECT "BOPORE"}

\section{Brief description}

In order to enhance the knowledge of the interaction of the hydrodynamic and hydrogeotechnical processes underlying the hydraulic performance and the wave loads on and underneath porous bonded revetments, the three year research project BoPoRe (Bonded Porous Revetments), funded by the German Research Council (DFG), was initiated. More specifically the project aims to focus on the effect of the porosity of revetments on wave run-up and run-down, wave-induced loads on and beneath the revetment and wave-induced pore pressures in the sand core under the revetment. Moreover, the effects of the roughness and the slope steepness of the revetment are also investigated. Based on the results, process-based and generic design formulae for bonded porous revetments that explicitly account for the porosity, the roughness and further parameters of the structure and the wave conditions will be developed.

For this purpose, extensive model tests will be conducted at a scale of 1:5 as compared to the aforementioned large-scale tests in GWK supplemented by a more systematic parameter study using a validated numerical model which is under development in the frame of another $\mathrm{PhD}$ project (Alcérreca Huerta \& Oumeraci 2012b). The usefulness of such an approach has been proved by Foyer \& Oumeraci (2012) who used the numerical model COBRAS-UC to extend the range of structure parameters and wave conditions tested in the Large Wave Flume (GWK) (Oumeraci et al. 2010)

Furthermore, the aforementioned results of large-scale investigations (Oumeraci et al. 2010 \& Oumeraci et al. 2012) can be used to possibly quantify scale effects in the 1:5 smaller scale model tests. Therefore, selected large-scale tests will be reproduced in small scale together with analysis of numerical investigations. In addition, numerical simulations using the model being developed by Alcérreca Huerta \& Oumeraci (2012a) will also be used for this purpose.

The processes on, within and beneath the revetment are affected by several parameters, including foreshore slope, structure parameters (e.g. slope angle, porosity and roughness) and wave conditions (water depth, wave height and period). The planned scale model tests will particularly focus on the effect of the porosity on the hydraulic performance and the wave loading of revetment and its foundation. In addition, it is also planned to vary the roughness and the slope steepness of the revetment in order to quantify the relative contributions of these effects separately.

Therefore, a systematic variation of the porosity, the slope steepness, and the roughness will be performed. The different bonded porous revetments will be subjected to both regular waves and JONSWAP-spectra. The testing programme will include measurements of the incident wave 
parameters, the wave run-up height and the wave induced pressures in different layers of the revetment including the pore pressures in the sand layer beneath the revetment. In fact, the transient pore pressures in the sand layer underneath bonded porous revetments were found to significantly affect the stability of the foundation (Oumeraci et al. 2012). To which magnitude the porosity will affect these processes represents one of the main objectives of the BoPoRe-project.

Before starting with the systematic model scale tests with a more complicated experimental setup, preliminary tests were first conducted using a much simpler model set-up. The first results of the first phase of these preliminary tests are reported below.

\section{Preliminary small scale model tests and first results}

Experimental set-up and testing programme (Phase 1). The first step of this research work is the conduction of preliminary model tests using a model to vary the slope angle, roughness and porosity of the revetment. The model set-up of phase 1 of these preliminary tests is sketched in Figure 9, also showing the deployed measuring devices. In this first phase, the slope of the revetment was kept constant (1:3) and 9 configurations by varying the porosity and roughness of the revetment were tested systematically for a very wide range of wave conditions (surf similarity parameters $\left.\xi_{\mathrm{m}-1,0}=0.93-7.21\right)$

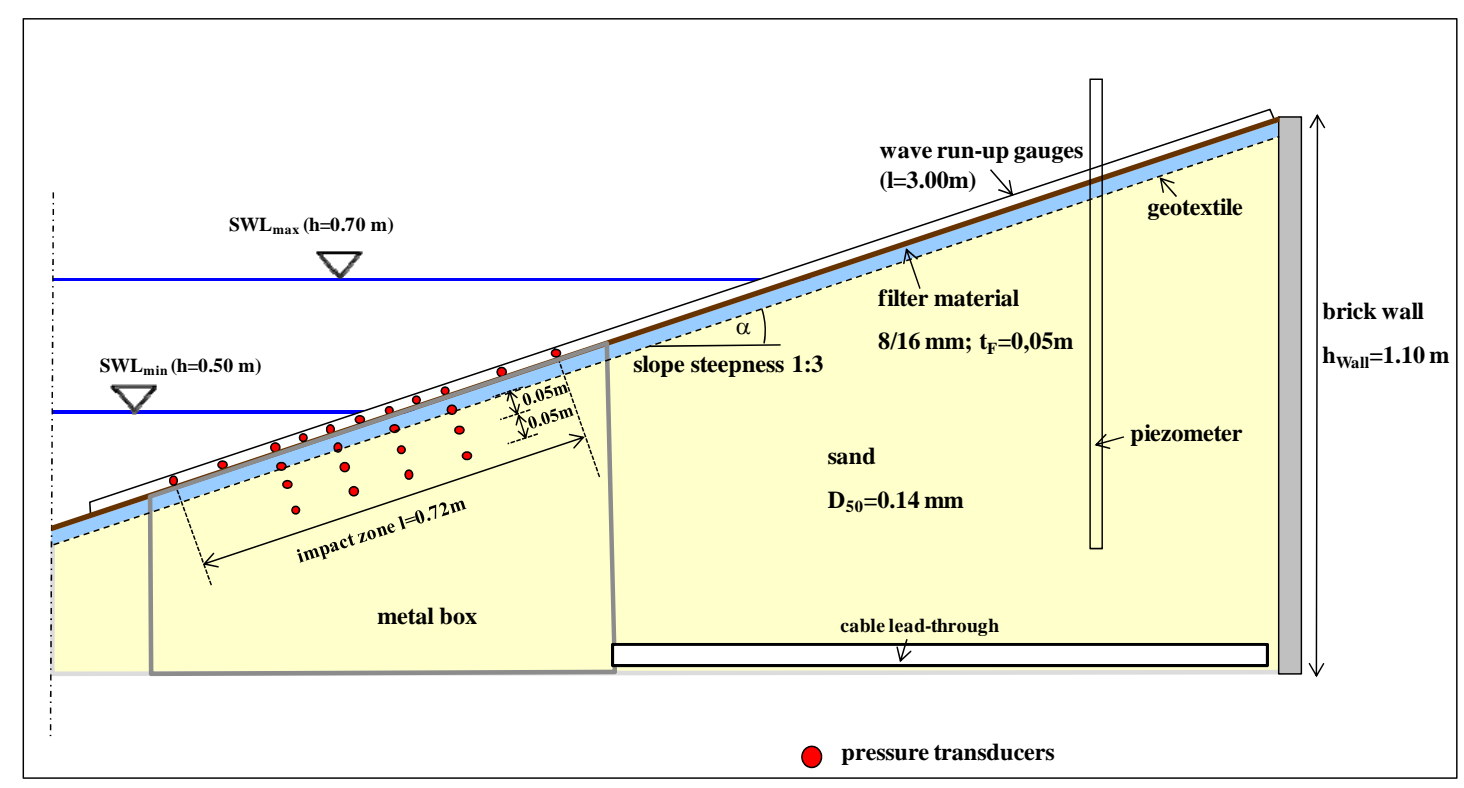

Figure 9. Model set-up for phase 1 of the preliminary tests with a slope steepness of 1:3

The revetment model was constructed in front of a brick wall with a height of $1.10 \mathrm{~m}$. A sand with a diameter $\mathrm{D}_{50}=0.14 \mathrm{~mm}$ was used for the sand core. The filter layer, made of crushed stones $8 / 16 \mathrm{~mm}$, was placed on the sandy substructure with a geotextile in between to prevent an out washing of the sand material. The "cover layer" was placed on top of the filter material.

23 pressure transducers (PT) were used, where 11 were placed on the revetment, and 4 PTs were placed in different layers underneath the revetment: at the bottom of the filter layer, on the geotextile, and in the sand in a depth of $5 \mathrm{~cm}$ and $10 \mathrm{~cm}$, respectively. Furthermore, the wave run-up and rundown were measured by run-up gauges and the water table in the sand by means of a wave gauge placed in a tube in the sand, here called piezometer (Figure 9). The water depth was varied from $0.5 \mathrm{~m}$ to $0.7 \mathrm{~m}$ in order to allow the waves to break within the location where most of the pressure transducers were installed (Figure 9). The 11 pressure transducers on the revetment were situated in a water-proof metal box where they were fixed in the cap of the box. During the experiments, the cap was flushmounted with the revetment cover layer. This construction was required to ensure a fast change of the cover layer without moving the pressure transducers.

For the simplified model, the porous cover layer is replaced by galvanised metal sheets with a thickness of $1.5 \mathrm{~mm}$. Three different sheets are chosen: An impermeable metal sheet and two perforated metal sheets with a defined hole amount leading to a vertical "porosity". The permeable metal sheets were perforated with regularly arranged holes with a diameter of $4 \mathrm{~mm}$ or $8 \mathrm{~mm}$, and a 
distance between hole centres of $8 \mathrm{~mm}$ or $11 \mathrm{~mm}$, respectively, leading to a porosity of $23 \%$ or $48 \%$, respectively.

For the metal box with the pressure transducers and for the run-up gauges, holes were cut in the particular metal sheet. Like the cap of the metal box also the run-up gauges were flush-mounted with the metal sheet.

The different roughnesses were achieved by the fixation of roughness elements made of wood $(\mathrm{L} / \mathrm{B} / \mathrm{T}=0.10 / 0.06 / 0.04 \mathrm{~m})$ on the revetment. The elements were arranged in two different layouts (see Figure 10) on the metal sheets to get two significantly different roughnesses described by a covering index, which is defined as the surface covered by the roughness elements as related to the total surface.

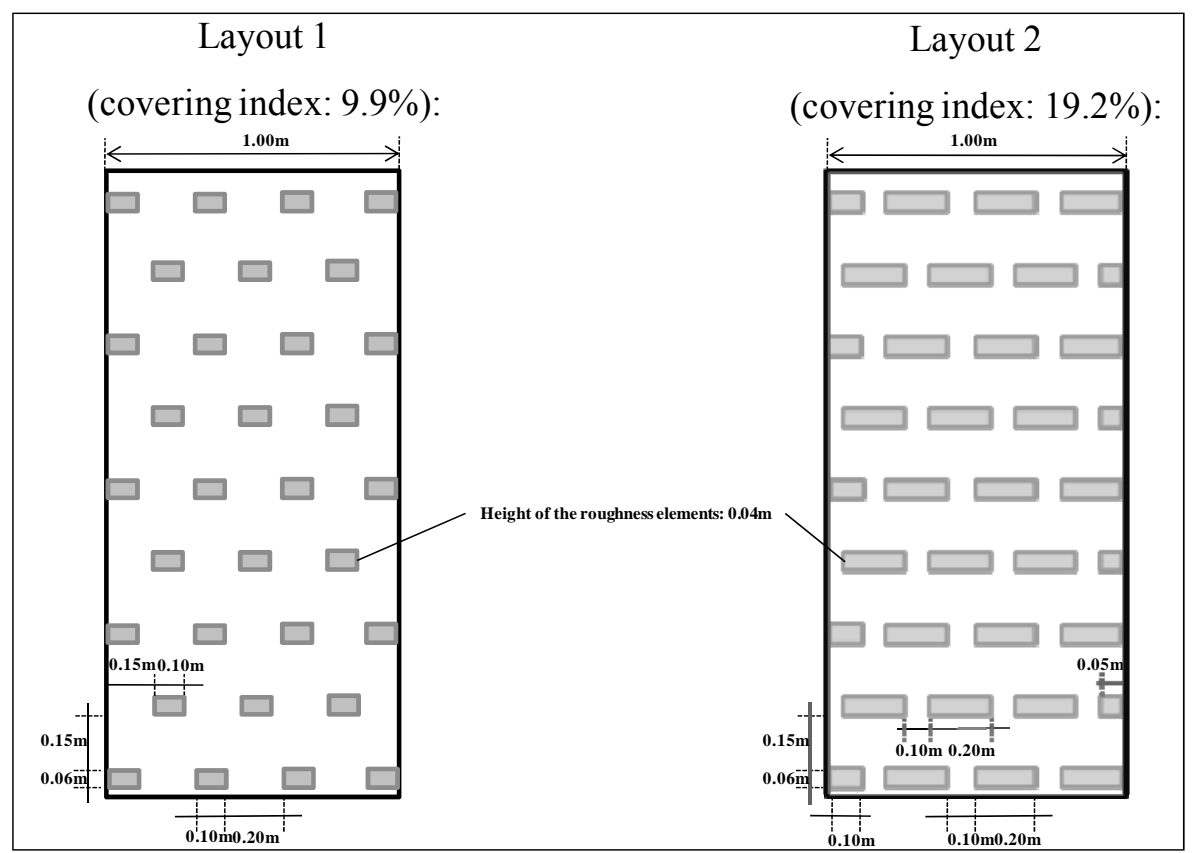

Figure 10. Layouts of roughness elements on the slope, left: covering index $9.9 \%$, right covering index $19.2 \%$

The combined variation of porosity (p0, p1 \& p2) and roughness (r0, r1 \& r2) resulted in 9 model configurations as defined in Table 1:

\begin{tabular}{|l|c|c|c|c|c|c|}
\hline \multicolumn{6}{|c|}{ Table 1. Configurations investigated during the first phase of the preliminary scale model tests } \\
\hline Configuration & $\begin{array}{c}\text { Porosity 0 } \\
\mathrm{p}=0 \%\end{array}$ & $\begin{array}{c}\text { Porosity 1 } \\
\mathrm{p}=23 \%\end{array}$ & $\begin{array}{c}\text { Porosity 2 } \\
\mathrm{p}=48 \%\end{array}$ & $\begin{array}{c}\text { Roughness 0 } \\
\text { smooth }\end{array}$ & $\begin{array}{c}\text { Roughness 1 } \\
\text { Layout 1 }\end{array}$ & $\begin{array}{c}\text { Roughness 2 } \\
\text { Layout 2 }\end{array}$ \\
\hline p0r0 & $\begin{array}{c}\mathrm{X} \\
\text { p0r1 }\end{array}$ & $\mathrm{X}$ & & $\mathrm{X}$ & $\mathrm{X}$ & \\
p0r2 & $\mathrm{X}$ & $\mathrm{X}$ & & $\mathrm{X}$ & $\mathrm{X}$ \\
p1r0 & & $\mathrm{X}$ & & & $\mathrm{X}$ & \\
p1r1 & & $\mathrm{X}$ & $\mathrm{X}$ & $\mathrm{X}$ & & $\mathrm{X}$ \\
p1r2 & & & $\mathrm{X}$ & & $\mathrm{X}$ & \\
p2r0 & & & $\mathrm{X}$ & & & $\mathrm{X}$ \\
p2r1 & & & & & & \\
p2r2 & & &
\end{tabular}

To visualize the test results and to review possible inconsistencies during data analysis two digital video cameras were used. One was placed on top of the wave flume to record the wave run-up and rundown during the different tests. The other camera was situated in lateral position and recorded the breaking behaviour of waves during the tests through a flume window. A photo of the whole model setup (here configuration p0r2) can be seen in Figure 11. It has to be noted that the revetment model was divided lengthwise into two $1 \mathrm{~m}$-sections in the $2 \mathrm{~m}$-flume, where the described model set-up can be seen on the left side in Figure 11. The right part of the revetment model was built of a rough wooden sheet with similar reflection properties. 


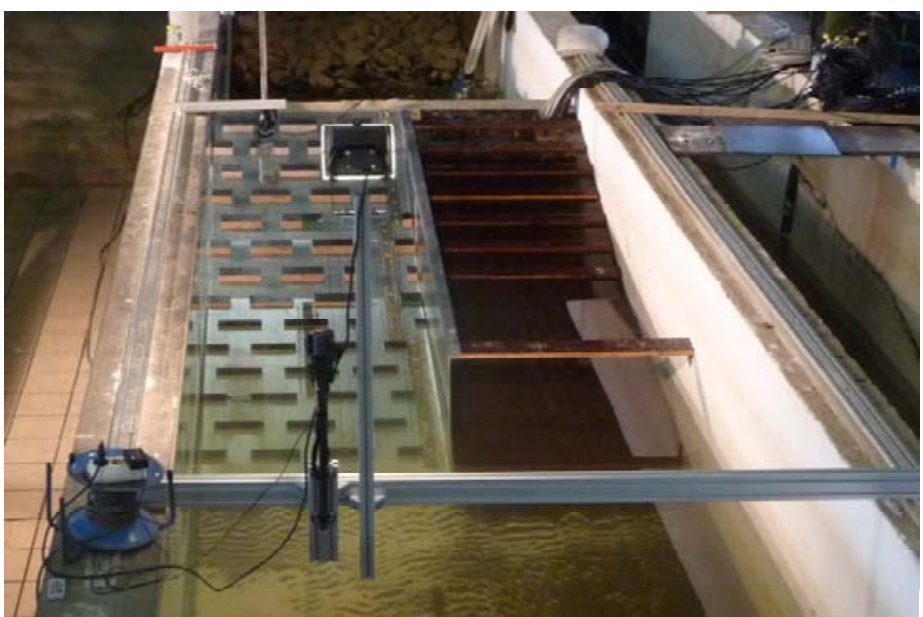

Figure 11. Model set-up (here: configuration p0r2) in the $2 \mathrm{~m}$-wave flume of Leichtweiss-Institute

Each of the 9 revetment configurations was subjected to the same wave conditions (Table 2) including 14 tests with regular waves (16-150 waves each, dependent on the wave period), 5 tests with wave spectra ( 600 waves each) and 3 solitary waves. Wave heights were chosen between $0.08 \mathrm{~m}$ and $0.25 \mathrm{~m}$ with wave periods from $1.0 \mathrm{~s}$ up to $6.0 \mathrm{~s}$. Consequently, a wide range of surf similarity parameters $\xi_{\mathrm{m}-1,0}$ between 0.93 and 7.21 resulted. This is necessary to cover the full range of wave loading conditions, i.e. from impact load to pulsating wave load conditions. Test with small surf similarity parameters $\xi_{\mathrm{m}-1,0}<1.5$ were also considered, because there were only few experiments in the aforementioned large-scale tests in the Large Wave Flume and no tests were performed for surf similarity parameters under 1.0 .

\begin{tabular}{l} 
Table 2. Test programme for each of the 9 revetment configurations in Table 1 (R = regular waves, \\
S = wave spectra) \\
\hline \multirow{2}{*}{}
\end{tabular}

In case of irregular wave loads JONSWAP wave spectra with 600 waves were chosen. In the preliminary tests the focus was made on the generation of regular waves since the idea was to better understand the behaviour of wave loading for different porosities and roughnesses. In total, 210 model tests were performed with 9 different configurations during this first phase of preliminary tests.

First results (Phase 1). In this section, first results from the regular wave tests performed in Phase 1 (revetment slope of 1:3) of the preliminary experiments are briefly discussed.

The time series of wave run-up and run-down on a smooth $(\mathrm{r}=0)$ revetment are exemplarily shown in Figure 12 for the 3 tested porosities $\mathrm{p}=0 \%, 23 \%$, and $48 \%$. The selected test for regular waves with a height of $\mathrm{H}_{\mathrm{m}}=0.16 \mathrm{~m}$ and a period $\mathrm{T}_{\mathrm{m}}=3.0 \mathrm{~s}$ corresponds to non-impact load conditions, thus resulting in larger wave run-up than for impact loads. 


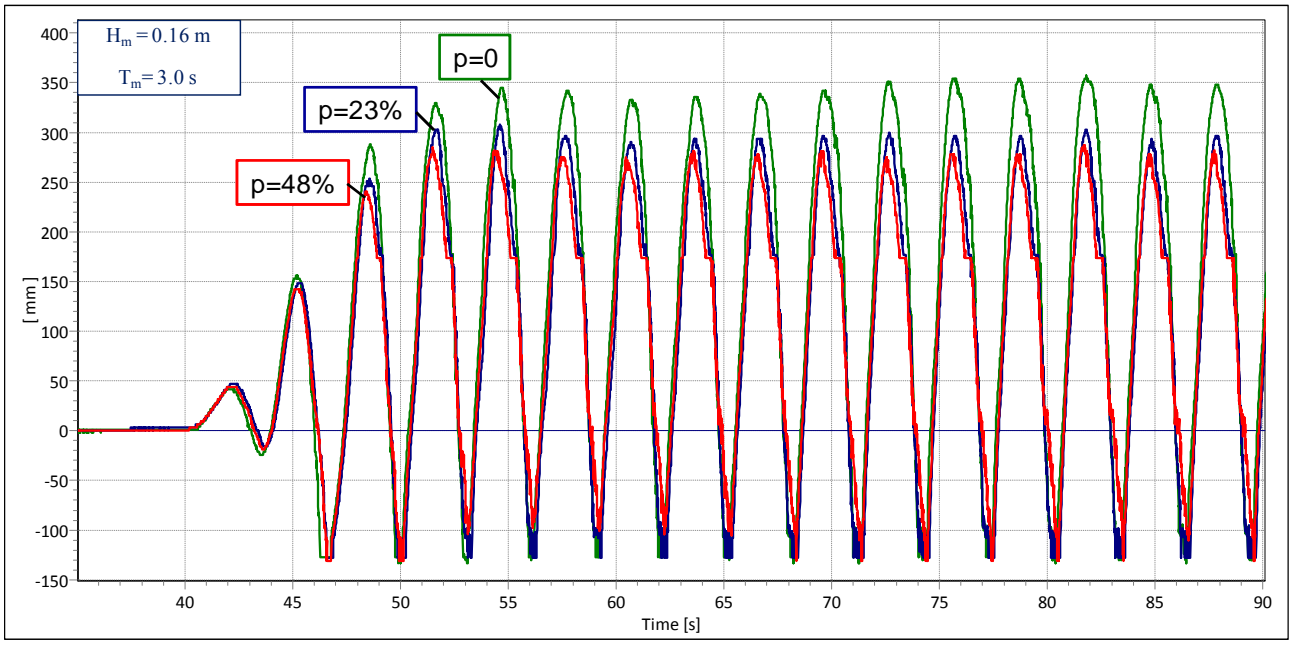

Figure 12. Time series of wave run-up and run-down for smooth revetments with different porosities (regular waves, $H_{m}=0.16 \mathrm{~m}, \mathrm{~T}_{\mathrm{m}}=3.0 \mathrm{~s}$ )

With increasing porosity the wave run-up height decreases significantly, due to the infiltration of the up-running water mass into the porous structure and the corresponding higher turbulences and energy dissipation. In this example, the highest wave run-up for the impermeable revetment was reduced by more than $20 \%$ on the high porous revetment. A similar value was suggested by the comparison of the results obtained for highly porous PBA revetment and the run-up formula for smooth impermeable revetments (Oumeraci et al. 2010). The effect of the porosity on wave run-down is less distinct and less pronounced. This might be due to the exfiltration processes which are more influenced by the porosity of the soil beneath the revetment than by that on the relatively thin revetment itself. Generally, similar results for the effect of porosities of the smooth revetment are also obtained for the different roughnesses tested. However, the effect of porosity by varying the roughness is much more complicated. For instance, it is not imperative that wave run-up decreases with increasing porosity. This is probably due to the combined effect of turbulence induced by the roughness elements and the infiltration/exfiltration processes which needs to be examined in more detail.

The time series of the wave-induced pressure on and beneath the high porous revetment are illustrated in Figure 13 for regular waves with a height of $0.25 \mathrm{~m}$ and a period of $1.5 \mathrm{~s}$ which corresponds to impact load conditions. The development of the wave-induced pressure is depicted in different layers on and beneath the revetment. For this purpose, the four pressure transducers located in the plane normal to the slope as shown in the principle sketch incorporated in Figure 13 were used.

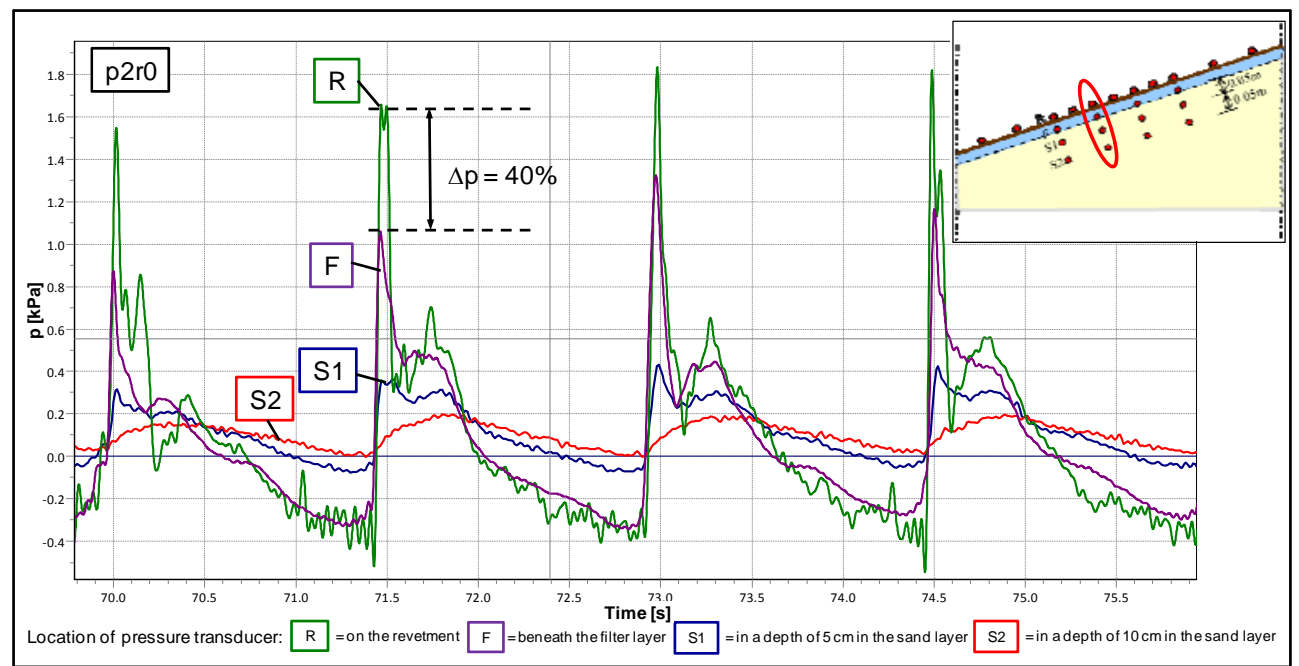

Figure 13. Time series of wave-induced pressures on and beneath a high porous and smooth revetment (regular waves, $\mathrm{H}_{\mathrm{m}}=0.25 \mathrm{~m}, \mathrm{~T}_{\mathrm{m}}=1.5 \mathrm{~s}$ ) 
The reduction of the pressure through the revetment becomes obvious. The pressure peak is damped up to $40 \%$ by the porous cover layer and the filter layer underneath. In the second sand layer in a depth of $10 \mathrm{~cm}$ only a very small reaction is visible so that the impact peak is damped completely in a depth of $10 \mathrm{~cm}$ in the sand. Furthermore, it is also obvious that the quasi-static loads are transferred nearly completely through the cover and the filter layer. The porous structure has almost no damping effect regarding quasi-static loads.

Just before the occurrence of the positive pressure peak, a negative pressure (upwards directed pressure gradient) occurs which rapidly decreases in the deeper soil layers beneath the revetment as was also observed in the PBA revetment tests (Oumeraci et al. 2010). The initial pressure beneath the filter layer (at the top of the sand layer) follows the pressure time history on the revetment due to the insignificant damping of the quasi-static loads by the relatively thin porous structure. The corresponding pressure gradient induces an outward directed flow (exfiltration) in the sand and a force which is also directed outward. For the design of porous revetments this gradient has to be properly taken into account as it may be crucial for the stability of the structure. This effect was responsible for a failure of the PBA revetment during the large scale tests reported by Oumeraci et al. (2010) and Oumeraci et al. (2012).

\section{Summary and outlook}

Bonded porous revetments may offer diverse advantages as compared to conventional nonbonded revetments due to their high porosity and the durable bond between the single elements. However, to date the current design practice does not explicitly the porosity. Moreover, the relative effect of the porosity and the roughness for different slope steepnesses on the hydraulic performance of the revetment and its foundation are still unknown. The crucial relevance of these aspects for the stability of the entire structure and its foundation has particularly been highlighted by the selected results of a comparative analysis of two large-scale test series performed in the Large Wave Flume (GWK) Hanover with two significantly different revetments: a highly porous and rough polyurethane bonded aggregate revetments (PBA) and an almost impermeable and relatively smooth interlocked pattern placed block revetments (IPPB), showing the necessity of a more extensive research programme to investigate the effect of the porosity and the roughness for different slopes of the revetment separately and systematically.

In order to fill these knowledge gaps and to improve the understanding of hydrodynamic processes on and under bonded porous revetments, the three year research project BoPoRe (Bonded Porous Revetments), funded by the German Research Council (DFG), was initiated.

The first results from the regular wave tests performed in Phase 1 (revetment slope of 1:3) of the preliminary experiments in the BoPoRe project by using 9 configurations for the porosity and roughness of the revetment subject to a wide range of wave conditions (surf similarity parameter $\xi_{\mathrm{m}-1,0}=0.93-7.21$ ) have confirmed the crucial relevance of the porosity for the wave run-up and rundown as well as for the wave-induced pressure beneath the revetment.

The next steps in the research project BoPoRe may be summarized as follows:

First, the data from Phase 1 of the preliminary tests with the simplified model set-up have to be further analysed, especially regarding the relative contribution of the porosity and the roughness on the different processes on and beneath the revetment with a particular focus on the processes in the sand layers beneath the revetment.

In phase 2 of the preliminary tests, the same test programme as for the slope 1:3 (Phase 1) will be performed for a slope 1:6.

The results of all the preliminary tests will be used to specify and to optimize the model set-up and the programme for more detailed tests with a more realistic bonded porous revetment reproduced at a scale 1:5 in relation to the large scale tests in GWK. This is important in order to quantify and eventually correct possible scale effects. For this purpose, a numerical model validated by the results of the large scale tests will also be applied. Moreover, the validated model will be used to extend the range of the tested conditions in the laboratory. The analysis of the data obtained from both numerical and laboratory data are then used (i) to better understand the processes involved in the wave-structurefoundation interaction and (ii) to develop simple and more generic formulae for the design of bonded porous revetments. 


\section{ACKNOWLEDGMENTS}

The project BoPoRe is funded by the German Research Council (DFG) (Project No. Ou 1/11-1). The model test data for the interlocked concrete block revetment was kindly provided by Prof. Dr-Ing. H. Schüttrumpf and Dipl.-Ing. F. Gier of the RWTH Aachen, Institute of Hydraulic Engineering and Water Resources Management (IWW).

\section{REFERENCES}

Alcérreca Huerta, J.C., H. Oumeraci. 2012a. Interaction of waves with a porous bonded revetment and its foundation: Process-based modelling; Numerical model in OpenFOAM (LWI-FOAM): Model equations and Validation Tests, Berichte Leichtweiß-Institut für Wasserbau, Technische Universität Braunschweig, Progress Report No. 2, Braunschweig, Germany, 68 pp.

Alcérreca Huerta, J.C., H. Oumeraci. 2012b. Wave loading and response of impermeable block revetments and highly porous PBA revetment: Comparative Analysis of large-scale datasets. Berichte Leichtweiß-Institut für Wasserbau, Technische Universität Braunschweig, Nr. 1024, Braunschweig, Germany, 141 pp.

CIRIA/CUR/CETMEF 2007. The Rock Manual, The use of rock in hydraulic engineering. CIRIA / CUR, CIRIA C683, 2nd edition, London, 1236 p.

EurOtop 2007. European Overtopping Manual, Pullen, T.; Allsop, N.W.H.; Bruce, T.; Kortenhaus, A.; Schüttrumpf, H.; Van der Meer, J.W., Kuratorium für Forschung im Küsteningenieurwesen: Die Küste, Heft 73.

Foyer, G., H. Oumeraci. 2012. Process analysis and model development for wave loading of porous bonded revetments, Berichte Leichtweiß-Institut für Wasserbau, Technische Universität Braunschweig, Progress Report No.3, Numerical Analysis, Braunschweig, Germany, 120 pp.

Gier, F., J. Mönnich, H. Schüttrumpf, J. Van der Meer. 2011. Experimentelle Untersuchungen zur Stabilität von verzahnten Setzsteindeckwerken, 41. Internationales Wasserbau-Symposium Aachen (IWASA) 2011, Aachen, Germany.

Gier, F., H. Schüttrumpf, J. Mönnich, J. van der Meer. 2012. Stability of interlocked pattern placed block revetments, Proceedings of 33rd International Conference on Coastal Engineering (ICCE), Santander, Spain.

Oumeraci, H., T. Staal, S. Pfoertner, G. Ludwigs, M. Kudella. 2010. Hydraulic performance, wave loading and response of Elastocoast revetments and their foundation- A large scale model study, Berichte Leichtweiß-Institut für Wasserbau, Technische Universität Braunschweig, Nr. 988, Braunschweig, Germany, 176p + Annexes.

Oumeraci, H., T. Staal, S. Pförtner, G. Ludwigs. 2012. Hydraulic performance, wave loading and response of PBA revetments and their foundations, Abingdon, UK: Taylor \& Francis, European Journal of Environmental and Civil Engineering, Volume 16, Issue 8, Special Issue: Coastal Engineering, pp. 953-980.

Schimmels, S., M. Vousdoukas, D. Wziatek, K. Becker, F. Gier, H. Oumeraci. 2012. Wave run-up observations on revetments with different porosities, Proceedings of 33rd International Conference on Coastal Engineering (ICCE), Santander, Spain.

Seelig, W.N. 1983. Wave reflection from coastal structures, Proceedings of Coastal Structures 1983, American Society of Civil Engineers (ASCE), pp. 961-973. 